\title{
STRENGTHENING THE VALUE OF HONESTY THROUGH ANTI- CORRUPTION EDUCATION IN SCHOOLS
}

\author{
LAILI FATHIA \& HASAN HARIRI \\ Education Master Program, FKIP Universitas Lampung. J1. Soemantri Brojonegoro No.1 \\ Bandar Lampung, Lampung - 35141, Indonesia
}

https://doi.org/10.37602/IJSSMR.2022.5105

\begin{abstract}
This article aims to describe the form of anti-corruption education to strengthen the value of honesty in schools, factors that encourage and hinder the implementation of anti-corruption education, as well as solutions to overcome obstacles in the implementation of anticorruption education. The research method used in this research is qualitative research with descriptive analysis. Anti-corruption education is carried out in two ways, namely honesty canteen and Pancasila and Citizenship Education learning. Supporting factors that affect the strengthening of honesty values are teacher examples, increased worship activities, and participation in organizational activities. The inhibitory factor is that the canteen often suffers losses due to lack of supervision and teacher assistance. Solutions to overcome these obstacles are to increase cooperation between teachers, increase supervision, carry out regular assistance, and support from family and community.
\end{abstract}

Keywords: Values of honesty, anti-corruption education, Pancasila education and citizenship

\subsection{INTRODUCTION}

Now the issue of the nation's morals is a trending topic in various circles ranging from the student level to the general public order. This can be known by the increasing cheating habits among students, ditching schools, lying to teachers and parents, inter-learning violence, stealing, gambling, smoking, drinking, free sex, corruption, collusion, and nepotism. One of the causes is the influence of globalization that provides the facilities needed by humans, both negative and positive (Asmani, 2012). (Hakim, 2016) argues that there are ten signs of the decline of the times from teenagers to watch out for, which are moral aspects related to the progress of the country. (Marianto, 2002) Interpreting Lickona's view with 10 signs of the decline of adolescence that leads to destruction, namely: (a) increased violence among students, (b) the use of bad language and words, (c) the influence of strong peer groups in acts of violence, (d) increased self-destructive behavior such as using drugs, alcohol, and free sex, (e) the blurring of good and bad guidelines, (f) decreased work ethic, (g) lower respect for parents and teachers, (h) lack of responsibility as a good citizen, (i) often lie, (j) antagonize and suspect each other.

Another opinion that asserts that the Indonesian nation is experiencing a moral decline is contained in the opinion of (Agustian, 2008) which states that there are seven moral crises amid Indonesian society, namely the crisis of honesty, the crisis of responsibility, not 


\title{
International Journal of Social Sciences and Management Review
}

\author{
Volume: 05, Issue: 01 "January - February 2022"
}

ISSN 2582-0176

thinking ahead, the crisis of discipline, the crisis of togetherness, the crisis of justice, and the crisis of concern. Various moral crises are not only felt by the Indonesian nation but other countries.

The above explanation confirms that there is a shift in values and morals in adolescents. This will be a problem for the survival of a nation if teenagers as the next generation of young people have bad morals, the possibility of bad behavior will be incarnated and spread to other bad behaviors such as lying habits and hedonistic traits that trigger the emergence of corrupt behavior. Various problems that occur indicate that the Indonesian nation today, especially among students, has experienced a moral decline and a shift in values. Efforts to overcome and prevent the spread of deviant behavior among adolescents, then one alternative that can be used is to strengthen character education in schools as one of the educational institutions.

School can be a good place to build character education learners. To achieve the success of educational goals, the role of teachers, principals, and parents of learners is needed because the school environment and family have an important role in supporting the success of achieving educational goals. In addition, there are several important elements in the formal curriculum in schools, namely hidden curriculum. As a hidden curriculum, the hidden curriculum is related to values that cannot be measured but can be noticed from the attitudes made by someone. Activities in the hidden curriculum are activities of educational units that are general and not directly related to a subject to help the development of learners according to needs, potential, talents, and interests (Amin, 2015). This activity is expected to have a contribution to the success of learners in school, especially for the success of character education.

The value of honesty needs to be instilled from the beginning in the formation of the character of learners such as in the process of teaching and learning in the classroom, extracurricular activities, habituation, and culture of character values. Character education development must be developed with various models of development carried out by schools to achieve goals following the mandate of Law No. 20 of 2003 on the National Education System. The purpose and function of national education are to form learners who are dignified, intelligent, faithful, capable, creative, and independent to create a generation that has a noble character and makes humans good (being good) and intelligent or being smart (Rukiyati, 2013). The purpose of national education is in line with the goal of Pancasila and Citizenship Education which forms the personality qualities of good citizens, responsible, independent, and love of the homeland (Hakim, et al, 2016). Character education is a potentially powerful tool in a child's critical process and adolescent development, so schools play a central role (Berkowitz, 2012)The School has a role in shaping the character of learners to be proactive, collaborative, as well as critical through character education. The comprehensive and effective application of character education will contribute to the progress of a country.

Character education developed in schools will indirectly form the character of citizenship in learners. School as an educational institution has a big role in developing character education because it acts as a centre for the culture of moral values for learners through a series of learning and extracurricular activities. Moral education and citizenship are important elements of whole-person education because it aims to foster positive values of learners and 


\title{
International Journal of Social Sciences and Management Review
}

\author{
Volume: 05, Issue: 01 "January - February 2022"
}

ISSN 2582-0176

attitudes (Mak, 2014). In this case, teachers as implementers of character education in schools have a very important role.

A teacher is used as an example and example for learners. (Arifin, 2011) said that no matter how good a curriculum is, the results depend heavily on what the teacher does in the classroom. This becomes a determining factor in the success of character formation including anti-corruption education. Educational interaction between teachers and learners has an effect on the self-concept of learners including honest character (Nurmalisa, 2018). The influence exerted by personal teachers, learners, learning atmosphere, and school environment affect the positive character of learners that occurs through anti-corruption education (Arifin, 2011).

Anti-corruption education is expected to form an honest personality to create a generation that has good character. On the other hand, the curriculum is the one that delivers learners following ideal expectations, not enough only the curriculum studied, but there is a strengthening of honesty values that theoretically very rationally affect learners, both regarding the school environment, classroom atmosphere, teacher interaction patterns with learners in the classroom, even on the policy and management of school management in vertical and horizontal interaction relationships (Rosyada, 2004). Experiences that can affect the character of learners and become the core of anti-corruption education include school habits apply discipline to its learners, the accuracy of teachers in starting lessons, the ability and way teachers master the classroom, teacher habits in dressing neatly, a neat school environment, orderly, comfortable, and the personality of noble learners. Through strengthening the value of honesty, of course, learners will be guided and prepared for the future by equipping learners with many skills such as noble personality and moral skills, leadership, discipline, patriotism, and creativity. The development of character education can be divided into four parts, namely teaching and learning activities in the classroom, daily activities in the form of educational unit culture, co-curricular and extracurricular activities, as well as daily at home and community order.

The application of anti-corruption education in the School is carried out through honest canteens. Anti-corruption education is important to do because eradicating corruption and instilling the value of honesty to learners has become a shared responsibility and needs to be done in various ways to campaign for anti-corruption education both in the school environment and the community continuously. In addition, strengthening the value of honesty can be done through the learning of the subjects of Pancasila and citizenship.

Pancasila and Citizenship Education is a subject in schools designed to prepare young citizens, so that later after adulthood can play an active role in society (Cogan, 1999). Pancasila and Citizenship Education is an education that can form the attitudes and behavior of good citizens. In a democracy, Pancasila and Citizenship Education should be a major concern. No task is more important than the development of responsible, effective, and educated citizens (Branson, 1998). Citizenship education is broadly formulated covering the process of preparing the younger generation to take on roles and responsibilities as citizens, and in particular, the role of education is included in schooling, teaching, and learning in the process of preparing citizens (Kerr, 1999). 


\title{
International Journal of Social Sciences and Management Review
}

\author{
Volume: 05, Issue: 01 "January - February 2022"
}

ISSN 2582-0176

Based on the above description, research on strengthening the value of honesty through Anticorruption Education in schools is carried out to discuss anti-corruption education that has been implemented by schools, driving factors and inhibiting the application of anticorruption education in schools, and solutions carried out to overcome obstacles in the implementation of anti-corruption education in schools.

\subsection{METHOD}

The method used in this study is the method of literature study. Literature studies are data collection techniques by conducting study studies of books, kinds of literature, notes, and reports that have something to do with the problem being solved." (Nazir,1988: 111). Literature studies are researched by studying and reading literature that has to do with strengthening the value of honesty through anti-corruption education in schools.

\subsection{RESULTS AND DISCUSSIONS}

Corruption is an act against the law, can harm the people and the state both done utilizing corruption and by embezzlement of state money so that many feel aggrieved and corruption is an act that is contrary to the values in Pancasila (Nurdjana, 2005). Combating corruption has become the responsibility of all parties and institutions in Indonesia both NGOs, schools, local governments, and central governments. Therefore, the value of honesty is urgent to be strengthened through existing Indonesian schools. To strengthen responsible and honest attitudes and behaviors, one of the efforts that can be done is to implement anti-corruption education. Anti-corruption education will be more effective if applied in various environments whether it is in schools, households, and community circles.

One of the basic values that need to be instilled in the formation of anti-corruption behavior is the value of honesty. If learners from an early age apply the value of honesty in their daily lives then for the future students can always behave honestly and anti-corruption. Strengthening the value of honesty and anti-corruption education in learners can be done in various ways, namely through honesty canteen, through directing, mentoring, incorporating anti-corruption materials into the curriculum, training, Scouting activities, through Pancasila and Citizenship Education subjects, religion, and various other activities.

\section{An Honesty canteen as a Form of Anti-corruption Education}

The honesty canteen schools is a long-term investment whose results cannot be seen in a short time. It takes years to figure out the success of efforts to strengthen the value of anticorruption in every student, but it is important for teachers who have tried to do something positive (Wibowo, 2013; Handoyo, 2009). The implementation of anti-corruption education through the habituation of honesty canteen is a conscious effort to provide understanding and prevention or eradicate corruption and can be a place to strengthen the values of honesty, discipline, openness, and responsibility to learners early on. The existence of an honesty canteen can contribute to shaping responsibility, independence, mindset, attitude, and anticorruption behaviour.

The application of the honesty canteen is an anti-corruption practice and a way to strengthen honesty in students in the school environment. Honesty canteens should be applied from an 


\title{
International Journal of Social Sciences and Management Review
}

\author{
Volume: 05, Issue: 01 "January - February 2022"
}

ISSN 2582-0176

early age because honesty canteens train learners to speak and do what they are, without covering up with lies (Wibowo, 2012). Strengthening the value of honesty through the honesty canteen has gone well. Honesty canteen in the school in its implementation is managed by learners accompanied by honesty canteen supervisors. Honesty canteens are placed in strategic places such as halls, teacher rooms, inside the classroom, and outside the classroom. All transactions proceed according to the awareness of paying the price of the goods purchased. The canteen is left open unattended by the cashier, all items are plastered with price tags and shoppers pay by putting money in a box. If the money put in the box needs a return, then the buyer takes his own return. All transactions run unsupervised, armed only with honesty.

The implementation of honesty canteens emphasizes habituation following anti-corruption behaviour. The values instilled in the honesty canteen are discipline, honesty, hard work, responsibility, courage, simplicity, fairness, openness, and caring. The establishment of honesty canteens in schools is expected to train the independence of learners and give rise to a deep understanding of the importance of anti-corruption education early on, especially the value of honesty. Honesty canteen can be used as a medium in channelling value education, as a means to strengthen honesty. Honesty canteen is also used for strengthening anticorruption attitudes and is expected to be the seed of anti-corruption later (Rabi \& Nachrowie, 2015; Gurning, et al, 2014). Many teachers in schools claim that the application of honesty canteens can have a positive impact and have a significant influence in strengthening the value of honesty to learners, can train the honesty of learners, learners learn to behave honestly and be obedient when no one is supervising, learning to be honest with themselves, can directly touch the awareness and attitude of learners. A value of life that becomes the forerunner of life free from corruption.

\section{Table 1. Honesty Canteen Goals in School}

\begin{tabular}{|c|c|}
\hline No. & Goals \\
\hline 1 & habituation of honest attitudes \\
\hline 2 & $\begin{array}{l}\text { more independent and will become the next generation of a better } \\
\text { nation for the future of the Indonesian nation }\end{array}$ \\
\hline 3 & medium for strengthening the value of honesty early on \\
\hline 4 & $\begin{array}{l}\text { attorney general's strategy in combating corruption is preventive, } \\
\text { repressive, and educative }\end{array}$ \\
\hline 5 & $\begin{array}{l}\text { process of breeding the formation of behavior and honest character of } \\
\text { learners in school and as a means of applying the values of honesty } \\
\text { that have been taught in school }\end{array}$ \\
\hline 6 & $\begin{array}{l}\text { trains learners to behave honestly, convey things as is, train learners to } \\
\text { be more responsible in every given action }\end{array}$ \\
\hline 7 & $\begin{array}{l}\text { train learners to obey the norms, rules, regulations that apply both in } \\
\text { school and in the community }\end{array}$ \\
\hline
\end{tabular}

Source: (Wibowo, 2012)

Based on the discussion above, it can be concluded that with the honesty canteen can provide habituation in students in school. Habituation of honest attitude and responsibility can train 


\title{
International Journal of Social Sciences and Management Review
}

\author{
Volume: 05, Issue: 01 "January - February 2022"
}

ISSN 2582-0176

students in school to always be responsible for the actions done and behave honestly by paying and taking money back. Habituation by transacting in the honesty canteen can increase confidence and motivation of learners to always be honest. Learners are given full confidence in conducting transactions in the honesty canteen honestly and responsibly.

Pancasila and Citizenship Education can equip learners with adequate intellectual knowledge and skills and practical experience that must be possessed by learners so that learners' competencies can be applied in the form of participation (Sapriya \& Winataputra, 2004). Therefore, Pancasila and Citizenship Education learning must rely on the competence of citizenship for all levels. Knowledge of citizenship, skills, values, and attitudes should be taught explicitly and systematically at every level of the classroom and should be integrated into the entire curriculum. It should be one of the main focal points in every classroom and help learners to gain skills in social studies. The curriculum helps learners to gain skills such as critical argumentation which is an essential skill for active democratic citizenship (Doğanay, 2012)

Pancasila and Citizenship Education has an important role to educate children of good character. Pancasila and Citizenship Education subjects are some of the subjects that have a large contribution to educating the nation's children and obeying the rules that apply (Halstead \& Pike, 2006). The purpose of Pancasila and Citizenship Education is to foster awareness of the human obligations of learners in the defence of the state by being imbued with the loving behaviour of the homeland as well as in the defence of state security with national and state awareness that has an integral comprehensive mindset.

The purpose of the Pancasila and Citizenship Education learning process is to prepare the younger generation to become citizens who have the knowledge, skills, and values necessary to participate / actively participate in their society (Bakry, 2014). Pancasila and Citizenship Education also has the goal of strengthening character values. The values contained in Pancasila and Citizenship Education are values that are related to the general public, moral education that cares about personal virtues or quality of character such as community values (Halstead \& Pike, 2006).

The integration of character education and Pancasila and Citizenship Education is one of the comprehensive and effective approaches (Arthur et al., 2008). The statement emphasizes the effectiveness of Pancasila and Citizenship Education and character education integrated into one unit in education. Pancasila and Citizenship Education and character education is complete unity. There is a link between Pancasila and Citizenship Education and character education Darling (2002); Althof \& Berkowitz, 2006). Character education is a special approach to the study of morals and (Bakry, 2014) educational values, which are closely related to Pancasila and Citizenship Education (Arthur et al., 2005)

In Indonesia, Pancasila and Citizenship Education is not only limited to the formation of a personality that Indonesians or Pancasila Education only. However, Pancasila and Citizenship Education also discuss social behaviors contained in society, including the formation of the character of the nation. By studying Pancasila and Citizenship Education, it is expected that Indonesian people become intelligent citizens and of good character (Fadil, 2013). Good character is the goal to be achieved from Pancasila and Citizenship Education. Concerning 


\title{
International Journal of Social Sciences and Management Review
}

\author{
Volume: 05, Issue: 01 "January - February 2022"
}

ISSN 2582-0176

the purpose of Pancasila and Citizenship Education who want to form the good character of citizens, then a Pancasila and Citizenship Education teacher is the spearhead of Pancasila and Citizenship Education learning in school must be able to educate values, morals, and character to its learners (Kerr, 1999; Lickona, 2009; Patrick \& Leming, 2001)

The purpose of Pancasila and Citizenship Education is in line with the vision of the school's mission that always applies the values of character education, one of which is the character of honesty. Through Pancasila and Citizenship Education teachers who always prioritize the value of honesty in the school environment, namely being honest in repeats, midterm assessments, and end-of-semester assessments are expected when the learners plunge into the community can maintain the good name of the school. A conducive and anti-rule-breaking environment can form good learners and can bring change to people's lives.

Anticorruption Education in Schools Strengthening honesty values does not always go well following expectations. Several factors affect the strengthening of honesty value, both supporting factors and inhibiting factors in strengthening the value of honesty. The following is a description of supporting factors and inhibiting factors in strengthening honesty values through anti-corruption education in schools.

Transparency and good examples of teachers are one of the driving factors in strengthening the value of honesty. In addition to providing examples and examples, worship, and study programs that routinely are also one of the driving factors for the strengthening of honesty. The third motivating factor is the participation of learners in the organization. The school develops many extracurricular activities namely basketball, core platoon, graphic design, journalism, choir, anti-drug task force, tahfidz Al Qur'an, mansa coustik, hadroh, scout, school consultative assembly, core platoon, youth scientific work, badminton, futsal, table tennis, Youth Red Cross (PMR), calligraphy, nature lovers, Mandarin, student council, choir, Scout, pencak silat, dance, futsal, and MTQ.

Extracurricular activities always train and foster learners to express themselves according to the talent of interests that exist in learners so that through these activities, the learners can know how to manage activities in the organization. Not only how to manage organizational activities but some values can be taken in these activities, namely the value of honesty displayed through the way of management in the organization, organizational administration, correspondence, and other activities that can increase the value of honesty of learners so that through these habits learners can feel the benefits. In the learning of Pancasila and Citizenship Education, several rules encourage the formation of honesty values, namely by being forbidden to cheat, if copying on the internet must include the source, accustomed to speaking a good and correct language. The application of delay SOPs, picket books, flag ceremonies is a routine activity to encourage the strengthening of the value of honesty of learners.

Several inhibitory factors can affect the strengthening of honesty values that do not work optimally. First, the environment around learners is less conducive. Lack of parental awareness to pay attention, attention, and care about the behavior of their children so that their children do not behave honestly in the honesty canteen, lack of discipline, and also lack of awareness of learners in participating in learning activities. Therefore, parents are required 


\title{
International Journal of Social Sciences and Management Review
}

\author{
Volume: 05, Issue: 01 "January - February 2022"
}

ISSN 2582-0176

to be able to choose an environment that supports their children's character education and avoids poor community environmental conditions. Because when the child is in a poor community environment, it will have a bad impact on the development of the child's personality or character. Likewise, schools as a formal education environment for a child, parents need to choose an environment that supports the local community and allows the implementation of such education (Kurniawan, 2013).

The opinion asserts that the success of educating children depends on environmental support. The second inhibitory factor comes from the personal learners who have not developed well. The phenomenon that occurs is the lack of awareness and honesty of learners so that there are learners who take without paying, there are also those who take more but count only a few, take more return, and some are in debt but forget to pay it. This is what causes honesty canteens to often lose. Nevertheless, the spirit of teachers in school remains high to continue to fight for the honesty of learners because honesty is one of the foundations or capital for learners to become good and successful people. The third inhibitory factor is the limitations of teachers in conducting supervision and management. Teachers have difficulty managing and supervising honesty canteens due to limited time and ample teaching hours. Teachers experience saturation and boredom so that there is an attitude of not wanting to know. Lack of mentoring and supervision from teachers makes learners cheat and make mistakes that can harm themselves. Faced in Strengthening the Value of Honesty in the School The family environment becomes a place of socialization that serves in the formation of character or personality as individual beings, social creatures, moral beings, and religious creatures. The experience of living together in a family environment contributes greatly to the formation of a child's personality.

The family is an educational environment that is quite effective and efficient to deliver the next generation in equipping themselves as well as possible so that they can become a reliable, skilled, and resilient generation. A harmonious, harmonious, and peaceful family affects the psychological condition and character of a child. Likewise, children become less devoted and even perform actions outside the morals of humanity, caused by disharmony in the family environment (Salim, \& Kurniawan, 2012). Although every child is born innocent, it does not mean that a lifetime is always close and doing good. It is quite possible in the development of his life to turn towards negative actions.

The positive potential may remain positive but it may also turn out to be negative. One of the factors that influences are the influence of the environment. However, if there is no opposite influence, a child is moved to realize his nature continuously throughout life (Mohamed et al., 1997). The opinion asserts that strengthening the value of honesty in children must certainly be supported by a safe family and community environment because of the emergence of a sense of security and kindness of learners caused by a safe and good environment and society.

Therefore, the environment is very influential in this life so the environment determines the good and bad of learners. If the environment is good then learners can follow it easily, for example, some friends often worship then the learners follow but if the environment is not good then the learners are affected and easily also follow the environment so that many students are drunk, gambling, fights, and other negative actions. Strengthening the value of 


\section{International Journal of Social Sciences and Management Review}

Volume: 05, Issue: 01 “January - February 2022”

ISSN 2582-0176

honesty in the younger generation is not only a responsibility and is left entirely to religious teachers and Pancasila and Citizenship Education only but the cooperation of all teachers in the school in the hope that through such cooperation can prevent learners who commit violations that can harm themselves and others. Supervision and regular mentoring are important because it is one of good and appropriate ways to increase awareness of learners who make mistakes. With the supervision and assistance of teachers, the problems that occur in schools can be reduced so that the school environment becomes peaceful, safe, and prosperous.

\subsection{CONCLUSION}

It can be concluded that the effort to strengthen the value of honesty in schools is to organize anti-corruption education by forming honesty canteens and through Pancasila and Citizenship Education learning. Factors that support the value of honesty are examples and examples of teachers, programmatic worship activities, routine studies, participation in organizations, strictly forbidden to copy and copy on the internet without including the source, Late SOPs, picket books, flag ceremonies, and extracurricular activities. The inhibiting factors are canteen honesty often loss and lack of assistance and supervision from teachers. The solution to overcome obstacles is to increase cooperation between teachers, conduct regular supervision and mentoring in the family and community environment.

\section{REFERENCES}

Agustian, A. G. (2008). Pembentukan habit menerapkan nilai-nilai religius, sosial dan akademik. Proceeding Seminar dan Lokakarya Nasional Restrukturisasi Pendidikan Karakter. Yogyakarta: Universitas Negeri Yogyakarta,

Arifin, Z. (2011). Konsep dan Model Pengembangan Kurikulum. Remaja Rosdakarya.

Arthur, J., Davidson, J., \& Lewis, M. (2005). Professional values and practice. Taylor \& Francis.

Arthur, J., Davies, I., \& Hahn, C. (2008). Sage handbook of education for citizenship and democracy. Sage.

Asmani, J. M. (2012). Buku Panduan Internalisasi Pendidikan Karakter di Sekolah. DIVA press.

Bakry, N. M. (2014). Pendidikan Kewarganegaraan. Pustaka Pelajar.

Berkowitz, M. W. (2012). Understanding effective character education. The Literacy and Numeracy Secretariat Capacity Building Series.

Branson, M. S. (1998). The Role of Civic Education: Center for Civic Education.

Cogan, J. J. (1999). Developing the CivicSociety: The Role of Civic Education. CICED. 


\section{International Journal of Social Sciences and Management Review}

Volume: 05, Issue: 01 “January - February 2022”

ISSN 2582-0176

Darling, L. F. (2002). The essential moral dimensions of citizenship education: what should we teach? The Journal of Educational Thought (JET)/Revue de la Pensée Educative, 229-247.

Doğanay, A. (2012). A curriculum framework for active democratic citizenship education. In Schools, curriculum and civic education for building democratic citizens (pp. 19-39). Springer.

Fadil, Y., \& Fauzi, I. A. dan E. S. . (2013). Peran Guru Pendidikan Pancasila dan Kewarganegaraan dalam Upaya Pembentukan Karakter Peserta Didik. 1, 1-14.

Hakim, e. a. (2016). Pendidikan Kewarganegaraan dalam konteks Indonesia. Jurnal Ilmiah Pendidikan Pancasila dan Kewarganegaraan.

Halstead, M., \& Pike, M. (2006). Citizenship and moral education: Values in action. Routledge.

Kerr, D. (1999). Citizenship Education: an international Comparison. England: National Foundation for Educational Research-NFER.

Lickona, T. (2009). Educating for character: How our schools can teach respect and responsibility. Bantam.

Marianto, H. (2002). Pendidikan karakter: Paradigma baru dalam pembentukan manusia berkualitas (character education: new paradigma to human capacity building).

Mohamed, Y., Abadi, M., \& Meutia, S. (1997). Insan yang suci: konsep'fithrah'dalam Islam. Mizan.

Nurdjana, I. (2005). Korupsi Dalam Praktik Bisnis: Pemberdayaan Penegakan Hukum, Program Aksi dan Strategi, Penanggulangan Masalah Korupsi. -.

Nurmalisa, Y. (2018). Pengaruh interaksi edukatif terhadap konsep diri siswa dalam belajar. Jurnal Ilmiah Pendidikan Pancasila dan Kewarganegaraan, 3(2), 215-219.

Patrick, J. J., \& Leming, R. S. (2001). Principles and Practices of Democracy in the Education of Social Studies Teachers. Civic Learning in Teacher Education. ERIC.

Rosyada, D. (2004). Paradigma Pendidikan Demokrasi Sebuah model Pelibatan Masyarakat dalam Penyelenggaraan Pendidikan. Jakarta.

Rukiyati, R. (2013). Urgensi Pendidikan Karakter Holistik Komprehensif Di Indonesia. Jurnal Pendidikan Karakter(2), 120651.

Sapriya, \& Winataputra, U. (2004). Pendidikan Kewarganegaraan: Model Pengembangan Materi dan Pembelajaran. Bandung: Laboratorium PKn-FPIPS UPI.

Wibowo, A. (2012). Pendidikan karakter: Strategi membangun karakter bangsa berperadaban. Pustaka Pelajar. 